\title{
ERROR PROCEDURE ANALYSIS BASED ON NEWMAN IN SOLVING LOGARITHM QUESTIONS REVIEW STUDENT'S BEGINNING MATHEMATICS ABILITY
}

\author{
M. Arie Firmansyah ${ }^{1}$, Dian Nopitasari ${ }^{2}$, Lely Lailatus Syarifah ${ }^{3}$, Rizki Yulianah ${ }^{4}$ \\ Universitas Muhammadiyah Tangerang, Jl. Perintis Kemerdekaan I/33, Cikokol, Tangerang, Banten, Indonesia
}

e-mail: lely141088@gmail.com

\begin{abstract}
Understanding the stages of problem solving in a material is the basic capital of students in meaningful learning. This study aims to determine the number of errors in the stages or procedures carried out by students in solving logarithmic problems. Another purpose of this study is to determine the factors that influence procedural errors based on students' high, medium, and low initial mathematical abilities in solving logarithmic problems. The method used in this research is descriptive qualitative. The population in this study were students of class $X$ MIPA MA Annida Al Islamy for the academic year 2020/2021. The subjects of this study were 3 students consisting of students with moderate, low, and high mathematical abilities. The validity of this research data using triangulation method. The research instrument used a multiple choice test consisting of 10 SMP UN questions and a descriptive test consisting of 5 logarithmic questions.
\end{abstract}

Keyword: procedural error, mathematical initial ability

\begin{abstract}
Abstrak
Pemahaman tahapan penyelesaian soal dalam suatu materi merupakan modal dasar bagi siswa dalam konteks pembelajaran yang bermakna. Penelitian ini bertujuan untuk mengetahui banyaknya kesalahan tahapan atau prosedur yang dilakukan siswa terhadap penyelesaian soal logaritma. Tujuan lain dari penelitian ini yaitu untuk mengetahui faktor-faktor apa saja yang mempengaruhi kesalahan-kesalahan prosedur berdasarkan kemampuan awal matematis tinggi, sedang, dan rendah yang dilakukan siswa saat menyelesaikan soal logaritma. Metode yang digunakan dalam penelitian ini adalah kualitatif deskriptif. Populasi penelitian ini adalah siswa kelas X MIPA MA Annida Al Islamy tahun ajaran 2020/2021. Subjek penelitian ini berjumlah 3 siswa yang terdiri dari siswa dengan kemampuan matematis sedang, rendah, dan tinggi. Data penelitian akan dianalisis menggunakan teknik reduksi data. Validitas data penelitian ini menggunakan metode triangulasi (tes, wawancara, dan dokumentasi). Instrumen penelitian ini menggunakan tes berbentuk pilihan ganda yang terdiri dari 10 soal UN SMP dan tes berbentuk uraian yang terdiri dari 5 soal logaritma
\end{abstract}

Kata kunci: kesalahan prosedur, kemampuan awal matematis

\section{INTRODUCTION}

Mathematics is a universal knowledge that underlies all modern technological developments today. Mathematics has an important role in various disciplines and develops human thinking power, and is a means of scientific communication about patterns that are useful for practicing logical, critical, creative, and innovative thinking. Mathematics is one of the subjects in the education system throughout the world, including Indonesia. There are still many students who think that mathematics is a difficult subject that makes students find it difficult to learn, understand, and complete mathematics. This can lead to a lack of students in mastering mathematical concepts, so it is possible for students to experience errors in 
solving math problems. Procedural knowledge is one of the knowledges that must be mastered in learning mathematics.

Students do not have the prerequisite knowledge in the material studied in mathematics, so it is possible to misunderstand concepts, principles, and procedures, as well as reasoning, and memorizing habits in the material studied in mathematics. Before students learn a material, it is necessary to understand and master the previous material. For example, in studying logarithmic material, students are required to master the basics of mathematical operations such as addition, subtraction, multiplication, division.

Logarithm is a mathematical operation that is the inverse of a power or an exponent. Logarithm is one of the materials in mathematics that is considered difficult by some students. Students sometimes can solve problems with the correct answer but they still experience procedural errors.

Newman, a teacher in mathematics studies in Australia introduced the error analysis method in 1977. The errors made by students in solving math problems in the form of story problems according to Newman include, reading errors, comprehension errors. , Transformation Error, Process Skills Error, and encoding error. To help identify what students might do in solving problems, Newman recommends 5 (five) question or command procedures to be used in interviews. The five procedures include: (1) To identify reading errors: "Let's read the question, and if you don't understand althought just one word please ask me"; (2) To identify misunderstandings: "Explain to me the question who you'r doing" (3) To identify transformation errors: "Explain to me, how you can get your answer?"; (4) To identify process skill errors: "Show me how you can answer the question and explain me what are you doing?"; (5) To identify errors in writing answers: "Write your answer from the question".

Factors supporting students' problems in solving math problems include internal and external factors. Internal factors are factors that come from oneself which includes interests, talents, and cognitive, while external factors are factors that come from outside oneself which include teachers, curriculum, facilities and infrastructure, and the environment. These factors can affect the low and high achievement of learning mathematics. Syah (2006) suggests that there are two factors that can affect the process and learning outcomes of students, namely internal factors and external factors. Internal factors are factors that exist in the students 
themselves, namely the level of student intelligence, abilities, attitudes, talents, interests and motivations of students. While external factors are factors that come from outside humans, namely family circumstances, curriculum, teaching methods and school facilities and infrastructure. To achieve optimal results, the internal and external factors need to be pursued as well as possible. The initial ability of students is one of the internal factors that affect student achievement because the initial ability can describe the readiness of students to take part in a lesson. Initial abilities are also seen as relevant skills that are possessed when starting a lesson. (Herawati, 2013).

\section{Procedure Error}

According to Widdiharto (2018), procedural errors or systematic errors are incompetence in matters related to basic logarithmic skills. Agree with Widdiharto, Soedjadi (Ulifa, 2014) procedural errors are errors in using algorithms (work procedures) for example errors in performing arithmetic operations. A student experiences procedural errors if students are not careful in carrying out calculations involving addition, subtraction, multiplication, and division, students do not have relevance skills, namely students make mistakes by using or entering all the numbers in the problem, even though there are some numbers that should be is not used, students do not continue the work process (Adhitama, 2011). Procedural error is the inability of matters related to using algorithms or working procedures.

According to Hastuti, I.D. (Adhitama, L., 2011, p.23) procedural errors include: a) not being able to perform the procedure, b) wrong in substituting variable values into the formula, c) student errors because students are less skilled in algebraic ideas, d) wrong in doing arithmetic operations, e) errors because students do not carry out the work process, $\mathrm{f}$ ) conclude without the right reasons.

Procedural errors are the inability to use algorithms, lack of skill in algebraic ideas, incorrect arithmetic operations and do not carry out the work process and conclude without the right reasons.

NEA (Newman's Error Analysis) was designed as a simple diagnostic procedure. Newman $(1977,1983)$ maintained that when a person attempted to answer a standard, written, mathematics word problem then that person had to be able to pass over a number of successive hurdles: Level 1 Reading (or Decoding), 2 Comprehension, 3 Transformation, 4 
Process Skills, and 5 Encoding. According to Newman, when students want to try to get the right solution to a mathematical problem in the form of a description problem, students are asked to do the following five activities: a) Read the question aloud, b) Say what questions you are asked to do, c) Tell me what method you used to find the answer, d) Show what steps you took and tell how you thought to find the answer, e) Write down the answer to the question.

The indicators that will be examined in the research of procedural errors in solving logarithmic problems in terms of the students' initial mathematical abilities include: (1) Students can understand the given logarithm problem and know what symbols are used. (2) Students understand what is asked in the logarithm problem. (3) Students can understand the models, formulas and arithmetic operations that will be used to solve problems. (4) Students know and can do the given procedure correctly. (5) Students can provide conclusions or final answers correctly.

\section{Initial Mathematical Ability}

According to Suja'I (2008) ability can also be called competence. The word competence comes from the English "compence" which means ability, power, authority, skill, knowledge, and ability and authority. So the word competence comes from the word competent which means having the ability and skill in his field so that he has the authority or authority to do something within the limits of his knowledge. Competence is a combination of three educational domains which include the realm of knowledge, skills and attitudes that are formed in the mindset and act in everyday life. On this basis, competence can mean knowledge, skills, and abilities that are controlled by someone who has become part of him so that he can perform cognitive, affective and psychomotor behaviors as well as possible. Ability is the knowledge and skills that are mastered by every individual who can perform psychomotor, affective, and affective behaviors so that he has the authority or authority to do something within the limits of his knowledge.

According to Kendeou \& Broek (2007) in (Firmansyah, 2017), students' understanding of learning materials is influenced by their initial abilities. The formation of initial abilities is influenced by the quality of learning experienced by previous students. If the previous learning is not effective, then the learning outcomes are not in accordance with the goals that have been set. If this happens, then to continue or understand the next material the student 
will have difficulty because of the low level of knowledge he has from the previous material or the prerequisite material for the next material.

Initial ability greatly affects students in understanding the subject matter. The quality of learning experienced by previous students affects the formation of initial abilities. Students will have difficulty if the level of knowledge and skills possessed is lower than the prerequisite material for the previous material. Early mathematical abilities are knowledge and skills that should have been mastered before students proceed to new lessons or advanced lessons.

\section{METHODS}

This study uses descriptive qualitative research methods. The research will be carried out at MA Annida Al Islamy, West Jakarta, for the 2020/2021 academic year. The subjects in this study were students of class X MIPA Annida Al Islamy, West Jakarta. Subjects will be taken as many as 3 students with low, medium, and high mathematical abilities. With each category as many as 1 student.

The research instrument used to collect data was triangulation method (test, interview, and documentation). There are two tests given to students, the first is an initial mathematical ability test with 10 multiple-choice questions and the second is a procedural error test with 5 essay questions. The test given to students aims to find out procedural errors made by students when solving logarithmic problems. Before the questions are given as tests to students, the questions are validated by experts to find out that the questions are in accordance with the indicators used.

\section{RESULTS AND DISCUSSION}

This research was conducted to find out procedural errors made by students in solving logarithmic problems in terms of students' initial mathematical abilities. This study also looks for factors that cause students to make mistakes in solving logarithmic problems at MA Annida Al Islamy in class X odd semester of the 2020-2021 school year. The material used in the initial mathematical ability test is logarithmic prerequisite material, while the procedural error test uses logarithmic material. Categorization of students in early mathematical ability is used as a reference material for selecting samples to be tested with procedural error tests.

Table 1. Mathematical Initial Ability Test Results

\begin{tabular}{ccc}
\hline Score & Category & Total Students \\
\hline Score $<53$ & Low & 5 \\
$53 \leq$ Score $<98$ & Average & 11
\end{tabular}


Table 1 shows that students who have low initial mathematical abilities are 5 students, while students who have moderate initial mathematical abilities are 11 students and those who have high mathematical initial abilities are 4 people. The results of the student's initial mathematical ability test were then taken as many as 3 people as research subjects, namely: one person has high initial mathematical ability based on norm referenced evaluation (Sugiyono, 2016), one person has moderate initial mathematical ability and one person has low initial mathematical ability.

Table 2. Research subject

\begin{tabular}{cc}
\hline Subject & Category \\
\hline S01 & Low \\
S02 & Average \\
S03 & High \\
\hline
\end{tabular}

The selected research subjects were then asked to take a written test in the form of a description to find out students' procedural errors, after the written test was carried out, it was followed by an interview test on each subject. The results of the written test and the results of student interviews are the data to be analyzed in this chapter. The data is described according to the steps of procedural errors based on Newman which include reading errors, understanding errors, transformation errors, processing skills errors, and writing answers errors. Furthermore, the data were analyzed based on the initial mathematical ability and procedural errors given. To determine the location of the mistakes made, namely by analyzing the wrong answers of students by combining the results of student work with the results of interviews. In the results of this study, researchers analyzed the types of student errors based on the Newman procedure according to students with high, medium, and low abilities

1. Types of Student Errors in Solving Problems Based on Newman Error Analysis (NEA) Procedures According to High Ability Students

a. Reading Error (Reading Error)

Reading errors are errors made by students when reading questions. Reading errors occur when students are unable to get important information contained in the problem. Mistakes made by students in this aspect, among others, students misdetermined the information in question from the problem, such as a matter of logarithmic material containing letters and roots. there are even students who do not understand the logarithmic material. The data obtained from the results of tests and interviews of high-ability students in this study 
were students who were able to read and were able to retrieve important information from the questions. This can be seen from several research findings, namely students can take important information correctly in the transformation process, namely being able to determine what is known in the question and what is asked in the question. So in this type of reading error, according to Newman, high-ability students have been able to read correctly. b. Error Understanding (Comprehension Error)

Misunderstanding the problem is an error made by students after students are able to read the problems in the problem but do not know what problems they must solve.

Errors made by students in this type can be seen from students who do not write down what is known and what is asked by the question or only write one of them on the answer sheet. In addition, most of the students wrote down things that were known and asked by the questions, but were wrong in capturing the information contained in the questions so that students could not solve the problems correctly and precisely.

The data obtained from the results of tests and interviews of high-ability students in this study were students who were able to understand the question. This can be seen from several research findings, namely students are able to determine what is known in the question and what is asked in the question. So in this type of understanding error (Comprehension Error) according to Newman, high-ability students have been able to understand correctly

\section{c. Transformation Error}

Transformation error is an error that occurs when students have correctly understood the question of the given problem, but failed to choose the right mathematical operation to solve the problem.

This type of error made by students can be seen from students who are not able to choose a formula, or are wrong in using the formula to solve the problem in the problem. In addition, most of the students were correct in determining the initial formula used, but did not write down the next formula to solve the problem completely. Or in other words, students are not able to determine the steps of completion by combining the formulas that should be used to solve the problems in the problem.

The data obtained from the results of tests and interviews of high-ability students in this study were students who were able to complete the transformation error section. This 
can be seen from several research findings, namely students are able to determine the initial formula used, and have written the next formula to solve the problem. So in this type of transformation error (Transformation Error) according to Newman, high-ability students have been able to determine the formula correctly.

\section{d. Process Skill Error}

Processing ability error is an error made by students in the calculation process. The student is able to choose the approach he should take to solve the problem, but he is not able to calculate it.

There are several mistakes made related to this type of error, apart from previous student errors (transformation errors), for example, students are not able to operate multiplication and addition correctly, besides that the students are also wrong in substituting values into the formula used.

The data obtained from the results of tests and interviews of high-ability students in this study were students who were not yet capable of the process ability section. This can be seen from several research findings, namely errors made by students in the calculation process. The student is able to choose a formula to solve the problem, but he is not able to calculate it. So in this type of process skill error, according to newman, high-skilled students are not able to calculate correctly.

\section{e. Final Answer Determination Error (Encoding Error)}

Errors in determining the final answer are errors in the completion process that cause students to be wrong in or not determining the final answer and not writing conclusions. This error occurs due to previous mistakes made by students.

2. Types of Student Errors in Solving Problems Based on the Newman Error Analysis (NEA) Procedure According to Students with Medium Ability

a. Reading Error (Reading Error)

Reading errors are errors made by students when reading questions. Reading errors occur when students are unable to get important information contained in the problem. Mistakes made by students in this aspect, among others, students misdetermined the information in question from the problem, such as a matter of logarithmic material containing letters and roots. there are even students who do not understand the logarithmic material. 
The data obtained from the results of tests and interviews of moderately capable students in this study were students who were able to read but were unable to retrieve important information from the questions. This can be seen from several research findings, namely students cannot take important information, this can be seen in the transformation process, namely students are not able to determine what is known in the question or what is asked in the question. So in this type of reading error, according to Newman, moderately capable students have not been able to read correctly.

b. Error Understanding (Comprehension Error)

Misunderstanding the problem is an error made by students after students are able to read the problems in the problem but do not know what problems they must solve.

Errors made by students in this type can be seen from students who do not write down what is known and what is asked by the question or only write one of them on the answer sheet. In addition, most of the students wrote down things that were known and asked by the questions, but were wrong in capturing the information contained in the questions so that students could not solve the problems correctly and precisely.

The data obtained from the results of tests and interviews of moderately capable students in this study were students who were unable to understand the question. This can be seen from several research findings, namely students are unable to determine what is known in the question or what is asked in the question. So in this type of understanding error (Comprehension Error) according to Newman, moderately capable students have not been able to understand correctly.

c. Transformation Error

Transformation error is an error that occurs when students have correctly understood the question of the given problem, but failed to choose the right mathematical operation to solve the problem.

The data obtained from the results of tests and interviews of moderately capable students in this study were students who were able to complete the transformation error section. This can be seen from several research findings, namely students are able to determine the initial formula used, and have written the next formula to solve the problem. So in this type of transformation error (Transformation Error) according to Newman, students with moderate abilities have been able to determine the formula correctly. 
d. Process Skill Error

Processing ability error is an error made by students in the calculation process. The student is able to choose the approach he should take to solve the problem, but he is not able to calculate it.

The data obtained from the results of tests and interviews of moderately capable students in this study were students who were not yet capable of the process ability section. This can be seen from several research findings, namely errors made by students in the calculation process. The student is able to choose a formula to solve the problem, but he is not able to calculate it. So in this type of process skill error, according to newman, moderately capable students are not able to calculate correctly.

e. Final Answer Determination Error (Encoding Error)

Errors in determining the final answer are errors in the completion process that cause students to be wrong or not to determine the final answer and not write conclusions. This error occurs due to previous mistakes made by students.

The data obtained from the results of tests and interviews of moderately capable students in this study were students who had not been able to determine the final answer. This can be seen from several research findings, namely errors made by students in the completion process which caused students to incorrectly determine the final answer and not write conclusions. So in this type of error determining the final answer (Encoding Error) according to Newman, moderately capable students are unable to determine the answer or conclusion correctly.

3. Types of Student Errors in Solving Problems Based on the Newman Error Analysis (NEA) Procedure According to Low Ability Students

a. Reading Error (Reading Error)

Reading errors are errors made by students when reading questions. Reading errors occur when students are unable to get important information contained in the problem. Mistakes made by students in this aspect, among others, students misdetermined the information in question from the problem, such as a matter of logarithmic material containing letters and roots. there are even students who do not understand the logarithmic material.

The data obtained from the results of tests and interviews of low-ability students in this study were students who were able to read but were unable to take important information 
from the questions. This can be seen from several research findings, namely students cannot take important information, this can be seen in the transformation process, namely students are not able to determine what is known in the question or what is asked in the question. So in this type of reading error, according to Newman, low-ability students have not been able to read correctly.

\section{b. Error Understanding (Comprehension Error)}

Misunderstanding the problem is an error made by students after students are able to read the problems in the problem but do not know what problems they must solve. Errors made by students in this type can be seen from students who do not write down what is known and what is asked by the question or only write one of them on the answer sheet. In addition, most of the students wrote down things that were known and asked by the questions, but were wrong in capturing the information contained in the questions so that students could not solve the problems correctly and precisely.

The data obtained from the results of tests and interviews of low-ability students in this study were students who were unable to understand the question. This can be seen from several research findings, namely students are unable to determine what is known in the question or what is asked in the question. So in this type of understanding error (Comprehension Error) according to Newman, low-ability students have not been able to understand correctly.

\section{c. Transformation Error}

Transformation error is an error that occurs when students have correctly understood the question of the given problem, but failed to choose the right mathematical operation to solve the problem. The data obtained from the results of tests and interviews of low-ability students in this study were students who were unable to complete the transformation error section. This can be seen from several research findings, namely students are not able to determine the initial formula used, but students write random answers to solve the problem. So in this type of transformation error (Transformation Error), according to Newman, lowability students do not able to determine the formula correctly.

\section{d. Process Skill Error}

Processing ability error is an error made by students in the calculation process. 
The data obtained from the results of tests and interviews of low-ability students in this study were students who were not yet capable of the process ability section. This can be seen from several research findings, namely errors made by students in the calculation process. The student is able to choose a formula to solve the problem, but he is not able to calculate it. So in this type of process skill error, according to newman, low-ability students are not able to calculate correctly.

e. Final Answer Determination Error (Encoding Error)

Errors in determining the final answer are errors in the completion process that cause students to be wrong or not to determine the final answer and not write conclusions. This error occurs due to previous mistakes made by students.

The data obtained from the results of tests and interviews of low-ability students in this study are students who have not been able to determine the final answer. This can be seen from several research findings, namely errors made by students in the completion process which caused students to incorrectly determine the final answer and not write conclusions. So in this type of error determining the final answer (Encoding Error) according to Newman, low-ability students are not able to determine the answer or conclusion correctly.

\section{CONCLUSION}

Based on the results of the research and discussion that have been described in the previous chapter, it can be concluded that the analysis of procedural errors based on Newman in solving logarithmic problems in terms of students' initial mathematical abilities from 3 categories can be seen that students who have high initial mathematical abilities experience fewer errors, because the subject This is able to pass all the indicators of procedural error given, it can be said that the procedural error value with high mathematical initial ability is higher than other subjects. (1) The description of each category in solving logarithmic problems in terms of students' initial mathematical abilities is as follows: a. Students with high early mathematical abilities are able to read and understand problems by writing and mentioning what is known and asked about correctly and correctly. Students with high early mathematical abilities can also transform formulas correctly and have good skills so that they are able to find answers correctly and precisely; b. Students with early mathematical abilities are able to read and understand problems by writing and mentioning what is known and 
asked correctly and correctly, but still experiencing errors in transforming formulas correctly and having skills that are good enough so that they experience not being able to find answers correctly and precisely; c. Students with low early mathematical abilities are able to read and understand problems by writing and mentioning what is known and asked correctly and correctly, but still experiencing errors in transforming formulas correctly and have poor skills so that students are unable to find answers correctly and precisely. 2) The factors that cause errors made by students in solving logarithmic problems in terms of students' initial mathematical abilities are described as follows: a. The causes of reading errors are that students are not fluent in reading and students' lack of knowledge about symbols commonly used in math problems; $b$. The causes of misunderstandings are that students do not understand what is known and what is asked, students are not careful in finding things that are known in the questions, and students rarely read questions related to logarithmic material; c. The causes of the transformation include that students are confused about having to use the right formula and don't know the formula that should be used, students don't understand the solution method used, students don't focus on solving problems, students don't understand logarithmic material, students don't like math, students rarely do examples of questions related to logarithmic material, and students have low cognitive abilities; $d$. The causes of process skill errors include students who have not mastered addition and multiplication operations, students are lazy to do addition and multiplication operations with large numbers, and students do not understand the calculations used; e. The cause of the error in writing the final answer is the result of previous mistakes and not understanding what is being asked in the question.

The suggestions that can be put forward are as input for educators to further assist students in the formation and habituation to improve good cognitive abilities.

\section{REFERENCES}

Abdurrahman, M. (2012). Anak Berkesulitan Belajar. Jakarta: Rineka Cipta.

Adhitama, L. (2011). Hubungan Antara Kepribadian dan Minat Belajar Anak Terhadap Prestasi Matematika Siswa Kelas VIII di SMP Negeri 1 Boyolangu Tahun Pelajaran 2010/2011. Skripsi.STAIN Tulungagung.

Amalia, S. R. (2017). Analisis Kesalahan Berdasarkan Prosedur Newman Dalam Menyelesaikan Soal Cerita Ditinjau dari Gaya Kognitif Mahasiswa. Aksioma. 
Astuti, S. P. (2015). Pengaruh kemampuan awal dan minat belajar terhadap prestasi belajar siswa. Jurnal Formatis, Vol.1, 68-75.

Firmansyah, M. A. (2017). Peran Kemampuan Awal Matematika dan Belief Matematika Terhadap Hasil Belajar. Prima: Jurnal Pendidikan Matematika, 55-68.

Hanun, F. (2010). Pengaruh Metode Pembelajaran dan Kemampuan Awal Terhadap Hasil Belajar Matematika. Widyariset, 123-134.

Haryati, T. (2015). Analisis Kesalahan Siswa SMP Kelas VII Dalam Menyelesaikan Soal Cerita Pemecahan Masalah Berdasarkan Prosedur Newman. Universitas Negeri Semarang: SKRIPSI.

Herawati, R. M. (2013). Pembelajaran kimia berbasis multipel representasi ditinjau dari kemampuan awal matematis terhadap prestasi belajar laju reaksi siswa SMA Negeri 1 Karang, Anyar tahun pelajaran 2011/2012. Jurnal Pendidikan Kimia (JPK) Prodi Pendidikan Kimia Universitas Sebelas Maret, 38-43.

Kulsum, U. (2019). Analisis Kesalahan Siswa Dalam Mengerjakan Soal Cerita Berdasarkan Prosedur Newman's Error Analysis (NEA) Ditinjau dari Kemampuan Matematis. IAIN Tulungagung, 123.

Reigeluth, C. M. (1999). Instructional design theoris and models vol. II. London: Lawrence erlbaum associates.

Sugiyono. (2016). Metode Penelitian Kuantitatif Kualitatif dan R\&D. Bandung: Elfabeta.

Suja'I. (2008). Inovasi Pembelajaran Bahasa Arab. Semarang: Walisongo Press.

Ulifa, S. N. (2014). Analisis Kesalahan Siswa dalam Menyelesaikan Soal Matematika pada Materi Relasi. Jurnal. ISSN: 2337-8166.

Widdiharto, R. (2008). Diagnosis Kesulitan Belajar Matematika SMP dan Alternatif Proses Remidinya. Yogyakarta: PPPPTK.

Wijaya, A. A., \& Masriyah. (2013). Analisis Kesalahan Siswa Dalam Menyelesaikan Soal Cerita Sistem Persamaan Linear Dua Variabel. MATHEdunesa, Vol 2, No 1.

Yolandia, Y. (2017). Analisis Kesalahan Siswa Dalam Menyelesakan Soal Cerita Berdasarkan Newman Error Analysis (NEA) Ditinjau dari Tingkat Kemampuan Awal Matematisnya Pada Materi Lingkaran. Pendidikan Matematika FKIP UNJA, 11. 